\title{
PARTISIPASI MASYARAKAT DALAM MITIGASI BENCANA DI KAWASAN RAWAN BENCANA III GUNUNG MERAPI DESA MRANGGEN
}

\author{
Oleh: \\ Evi Susanti ${ }^{1}$, Nurul Khotimah' \\ ${ }^{1}$ Mahasiswa Jurusan Pendidikan Geografi, FIS, UNY \\ ${ }^{2}$ Staf Pengajar Jurusan Pendidikan Geografi FIS \\ nurul_khotimah79@yahoo.co.id
}

\begin{abstract}
Abstrak
Penelitian ini bertujuan mengetahui: (1) mitigasi bencana yang tepat di Kawasan Rawan Bencana (KRB III) Gunung Merapi Desa Mranggen, 2) tingkat partisipasi masyarakat dalam mitigasi bencana. Penelitian ini merupakan penelitian deskriptif. Populasi dalam penelitian ini adalah seluruh Kepala Keluarga di Desa Mranggen sejumlah 1291 KK. Sampel diambil secara stratified random sampling. Pengumpulan data dilakukan dengan observasi, dokumentasi dan wawancara. Analisis data secara deskriptif menggunakan tabel frekuensi. Hasil penelitian menunjukkan (1) (a) mitigasi struktural berupa pembangunan Check dam, Sabo dam, Operit, Jembatan Gantung, Tanggul/Bronjong, Talud/Drainase, dan Jalur Evakuasi. (b) mitigasi nonstruktural meliputi penyusunan Standar Operasional Prosedur Penanggulangan Bencana Gunung Merapi, Prosedur Tetap Penanggulangan Bencana (Protap PB), Prosedur Evakuasi, Program Sister Village, Peta KRB, OPRB (Organisasi Pengurangan Risiko Bencana), Penghutanan, Sosialisasi PB dan Alat Komunikasi HT (Handy Talky). (2) Tingkat partisipasi masyarakat dalam mitigasi bencana menunjukkan bahwa ratarata skor nilai keseluruhan responden pada masing-masing tahapan partisipasi 22,64 atau $36 \%$ tergolong dalam tingkatan sedang.
\end{abstract}

Kata kunci: mitigasi bencana, Gunung Merapi, partisipasi masyarakat, Kawasan Rawan Bencana

\begin{abstract}
This research aims at finding: (1) the appropriate disaster mitigation in DisasterProne Areas of Merapi volcano in Mranggen Village, (2) the level of community participation in disaster mitigation. This research is a descriptive research. The research population include all households in Mranggen Village. The samples were taken using a stratified random sampling technique. The data collection was performed using observations, documentations and interviews. An analysis of descriptive data used frequency tables. The results show that: (1) (a) structural mitigations include the construction of check dams, Sabo dam, Operit, Suspension Bridge, Embankment/Gabion, gabion wall/Drainage and Evacuation Route, (b) non-structural mitigations include preparation of Standard Operating Procedure for Merapi Disaster Management, Disaster Management Procedure, evacuation procedure, sister village program, KRB map, disaster management organization, reforestration, socialization of disaster management and handy talky. (2) The participation level of community in disaster management shows that the average score of the overall respondents for each stage of participation reaches 22.64 or $36 \%$ which belong to the moderate level.
\end{abstract}


Keywords: disaster mitigation, Merapi Volcano, community particiation, Disaster-Prone Area

\section{PENDAHULUAN}

Gunung Merapi merupakan salah satu gunung berapi teraktif dan sangat berbahaya di Indonesia karena mengalami erupsi setiap dua sampai lima tahun sekali serta dikelilingi oleh permukiman yang cukup padat. Letusan Gunung Merapi pada tahun 2010, merupakan letusan besar yang bersifat eksplosif sehingga material letusannya tersebar ke seluruh lereng Gunung Merapi, mengisi sungai-sungai yang ada dari timur hingga utara. Bahaya letusan gunungapi dapat berpengaruh secara langsung (primer) maupun tidak langsung (sekunder) bagi kehidupan manusia.

Gunung Merapi terletak di Daerah Istimewa Yogyakarta dan Jawa Tengah. Lereng sisi selatan berada dalam administrasi Kabupaten Sleman, Daerah Istimewa Yogyakarta dan sisanya berada dalam wilayah Provinsi Jawa Tengah yaitu Kabupaten Magelang di sisi barat, Kabupaten Boyolali di sisi utara dan timur, serta Kabupaten Klaten di sisi tenggara. Ibukota Kabupaten Magelang merupakan salah satu kabupaten yang letaknya dekat dengan puncak Gunung Merapi, yaitu berjarak sekitar $30 \mathrm{Km}$. Salah satu kecamatan di Kabupaten Magelang yang memiliki potensi bencana letusan Gunung Merapi adalah Kecamatan Srumbung. Kecamatan Srumbung merupakan salah satu kecamatan yang termasuk ke dalam Kawasan Rawan Bencana (KRB) III Gunung Merapi, yang mempunyai tingkat paling berisiko terhadap ancaman letusan gunungapi.

Kecamatan Srumbung terdiri atas 17 desa, dengan jumlah penduduk sebesar 46.533 jiwa (BPS, 2010). Desa di Kecamatan Srumbung yang masuk ke dalam Kawasan Rawan Bencana III letusan Gunung Merapi terdiri atas 8 desa, diantaranya Desa Tegalrandu, Ngargosoka, Mranggen, Srumbung, Ngablak, Kemiren, Kaliurang, dan Nglumut. Desa Mranggen merupakan desa yang tidak hanya berpotensi terkena dampak primer letusan gunungapi, tetapi juga terkena dampak sekunder maupun tersier karena sebagian wilayahnya berada di bantaran Sungai Putih dengan jarak sekitar 11 kilometer dari puncak Gunung Merapi.

Masyarakat di KRB III memiliki berbagai alasan untuk tetap tinggal, meskipun mereka sadar akan besarnya kerawanan bencana yang harus mereka hadapi. Sebagian besar penduduk di Desa Mranggen bekerja sebagai petani salak pondoh dan penambang pasir atau batu yang berasal dari Gunung Merapi. Faktor lain yang menyebabkan masyarakat tetap bertahan di Kawasan Rawan Bencana ini karena mereka sudah tinggal bertahun-tahun dari peninggalan/warisan nenek moyang.

Melihat kenyataan kehidupan penduduk yang tetap tinggal di sekitar Gunung Merapi, maka sudah seharusnya mereka mempunyai upaya mitigasi bencana yang tepat. Masyarakat harus berpartisipasi dalam kegiatan mitigasi bencana sebagai upaya untuk mengurangi dampak dari bencana letusan gunungapi yang dapat dilakukan sebelum bencana itu terjadi, termasuk kesiapan dan tindakan-tindakan pengurangan risiko bencana jangka panjang. Kondisi yang ada di masyarakat adalah terbatasnya pengetahuan tentang mitigasi bencana, reaksi masyarakat terhadap penginformasian bencana masih lambat, serta orientasi pemikiran masyarakat saat menghadapi bencana yang juga masih sangat 
memprihatinkan karena mereka lebih mengutamakan harta benda dan ternak dibandingkan dengan keselamatan dan kesehatan keluarga.

Upaya mitigasi bencana tersebut bertujuan untuk menggali partisipasi masyarakat dalam pengurangan risiko bencana, baik dalam proses identifikasi masalah, perencanaan, pelaksanaan, pemanfaatan dan pemeliharaan, maupun evaluasi berbagai kegiatan penanggulangan bencana, dalam hal ini bencana letusan gunungapi. Kenyataan yang ada, tidak semua anggota masyarakat mau berpartisipasi dalam kegiatan mitigasi bencana. Kurangnya kesadaran masyarakat di Desa Mranggen untuk berpartisipasi dalam upaya mitigasi bencana merupakan masalah yang harus diselesaikan, mengingat keterlibatan masyarakat dalam pengurangan risiko bencana letusan gunungapi cukup efektif pada tingkat lokal.

Melihat pentingnya partisipasi masyarakat dalam upaya pengurangan risiko bencana di Desa Mranggen Kecamatan Srumbung sebagai Kawasan Rawan Bencana III tersebut, maka peneliti tertarik melakukan penelitian tentang "Partisipasi Masyarakat dalam Upaya Mitigasi Bencana di Kawasan Rawan Bencana (KRB) III Gunung Merapi Desa Mranggen Kecamatan Srumbung Kabupaten Magelang".

\section{METODE}

Penelitian ini merupakan penelitian deskriptif dengan analisis data kuantitatif, yang digunakan untuk mengetahui partisipasi masyarakat dalam upaya mitigasi bencana. Konsep geografi yang digunakan dalam penelitian ini meliputi konsep lokasi, jarak, keterjangkauan, pola, morfologi, dan deferensiasi area. Penelitian ini menggunakan pendekatan kelingkungan/ekologi karena berkaitan dengan interaksi masyarakat dengan lingkungan yang rawan bencana letusan gunungapi.

Variabel dalam penelitian ini adalah partisipasi masyarakat yang meliputi tahap identifikasi masalah, perencanaan, pelaksanaan, pemanfaatan dan pemeliharaan, serta evaluasi. Populasi yang akan menjadi sumber data dalam penelitian ini adalah seluruh Kepala Keluarga di Desa Mranggen yang masuk dalam Kawasan Rawan Bencana III Gunung Merapi Kecamatan Srumbung yang berjumlah 1291 KK. Metode pengambilan sampel yang digunakan dalam penelitian adalah proporsional sampel (proportional random sampling) yaitu suatu cara untuk memperoleh sampel yang representatif, pengambilan subjek dari setiap strata atau wilayah ditentukan seimbang atau sebanding dengan banyaknya subjek dalam masing-masing strata atau wilayah (Suharsimi Arikunto, 2006: 139). Sampel yang diperlukan dipilih secara random dengan menggunakan rumus formula Slovin sehingga menghasilkan sampel sebesar $100 \mathrm{KK}$. Desa Mranggen terdiri dari 14 dusun sehingga pengambilan sampel dilakukan pada 14 dusun tersebut.

Teknik pengumpulan data dalam penelitian ini menggunakan teknik observasi, wawancara dan dokumentasi. Teknik analisis data dalam penelitian ini menggunakan analisis data kuantitatif yaitu analisis non statistik dengan tabel frekuensi. Metode analisis tersebut dapat digunakan untuk mendeskripsikan partisipasi masyarakat dalam upaya mitigasi bencana yang diperoleh dari asumsi nilai skoring masing-masing tahapan partisipasi masyarakat, yang terbagi menjadi 3 parameter apakah dalam tingkatan rendah, 
sedang atau tinggi dengan menentukan interval skor menggunakan rumus sebagai berikut (Sutrisno Hadi, 2000: 12):

$$
T=\frac{\text { Jarak Pengukuran }(R)}{\text { Jumlah Interval }}
$$

Keterangan:

I = lear interval

$\mathrm{R}=$ nilai tertinggi dikurangi dengan nilai terendah

\section{HASIL DAN PEMBAHASAN}

\section{Upaya Mitigasi Bencana yang Tepat di KRB III Gunung Merapi Desa Mranggen Kecamatan Srumbung Kabupaten Magelang}

Penanggulangan bencana alam letusan Gunung Merapi di Kabupaten Magelang dilakukan dengan kegiatan mitigasi bencana sebagai kegiatan pengurangan risiko bencana untuk meminimalisir korban. Mitigasi yang dilaksanakan adalah mitigasi fisik (struktural) dan mitigasi non-fisik (non-struktural), terutama di Kawasan Rawan Bencana III yang memiliki tingkat paling berisiko terhadap ancaman bencana letusan Gunung Merapi.

\section{Mitigasi Struktural}

Upaya mitigasi struktural di Desa Mranggen sebagai Kawasan Rawan Bencana (KRB) III merupakan suatu upaya pengurangan risiko bencana melalui pembangunan fisik yang dapat melindungi masyarakat dari ancaman bencana letusan Gunung Merapi baik yang sifatnya primer maupun sekunder. Kegiatan mitigasi struktural Desa Mranggen antara lain Check dam, Sabo dam, Operit, Jembatan Gantung, Tanggul/Bronjong, Talud/Drainase, dan Jalur Evakuasi.

Check dam merupakan bangunan fisik yang digunakan untuk mengurangi laju aliran lumpur saat terjadi bencana banjir lahar hujan. Terdapat 6 buah Check dam yang dibangun di sepanjang Sungai Putih yang melintasi Desa Mranggen dari mulai bagian hulu tepatnya Dusun Salamsari sampai dusun paling akhir yaitu Dusun Pringsari.

Sabo dam merupakan bangunan fisik yang digunakan untuk menampung aliran lahar/lumpur agar volume lahar/lumpur yang mengalir ke arah hilir menjadi sedikit (berkurang). Bangunan Sabo dam ini biasanya berdekatan dengan bangunan Check dam sehingga masyarakat sulit membedakan antara keduanya, kemudian mereka menyebut keduanya hanya dengan sebutan "dam".

Operit merupakan jembatan serbaguna yang dapat berfungsi sebagai Sabo Dam saat terjadi banjir lahar hujan sehingga sering disebut sebagai Sabo Dam Operit. Bagian bawah dari Operit berfungsi menampung aliran lumpur saat banjir lahar hujan. Operit ini saat tidak terjadi bencana lahar hujan dimanfaatkan masyarakat sebagai jembatan yang menghubungkan Desa Mranggen dengan dusun-dusun di Desa Srumbung. Terdapat 2 operit yang dibangun di Sungai Putih yang melintasi Desa Mranggen, yaitu Sabo Dam Operit yang menghubungkan Dusun Grogolsari (Desa Mranggen) dengan Dusun Cabe Lor (Desa Srumbung), dan Sabo Dam Operit yang menghubungkan Dusun Pagersari (Desa Mranggen) dengan Dusun Cabe Kidul (Desa Srumbung). 
Jembatan gantung dibangun karena Sungai Putih berpotensi besar terhadap banjir lahar hujan sehingga jembatan ini lebih optimal sebagai penghubung jalur transportasi sekaligus sebagai upaya mitigasi bencana di Desa Mranggen. Jembatan Gantung yang dibangun di Desa Mranggen antara lain jembatan gantung yang menghubungkan Dusun Salamsari-Dusun Ngepos dan jembatan gantung Dusun Pringsari-Dusun Krajan Srumbung.

Tanggul atau bronjong merupakan pembangunan fisik sebagai upaya mitigasi bencana yang digunakan untuk menahan aliran air agar tidak sampai ke permukiman masyarakat mengingat terdapat 7 dusun di Desa Mranggen yang berada di sepanjang bantaran Sungai Putih.

Talud atau drainase adalah pembangunan fisik sebagai upaya mitigasi struktural yang berbentuk dinding saluran air di sepanjang jalan, yang digunakan untuk mengendalikan kelebihan air saat terjadi banjir agar tidak merusak jalan. Jalur evakuasi merupakan pengoptimalan jalan jalur terdekat menuju tempat evakuasi. Jalur evakuasi utama Desa Mranggen yang telah di aspal adalah jalur evakuasi dari Dusun Salamsari menuju TES (Tempat Evakuasi Sementara) yaitu Balai Desa Mranggen.

Check dam, sabo dam, operit, jembatan gantung dan tanggul/bronjong merupakan upaya mitigasi fisik di Desa Mranggen yang pembangunannya di bawah kewenangan BBWS Serayu Opak (Balai Besar Wilayah Sungai Serayu Opak) berkoordinasi dengan BPBD Kabupaten Magelang, serta DPU (Dinas Pekerjaan Umum) Kabupaten Magelang. Desa Mranggen sebagai daerah yang rawan bencana dan berbatasan langsung dengan Sungai Putih, dalam kegiatan pembangunan fisik tersebut terlibat dalam pemberian izin pelaksanaan pembangunan, serta pemberian saran/masukan dalam pembangunan fisik sebagai upaya penanggulangan bencana.

Pembangunan talud/drainase di Desa Mranggen merupakan pembangunan fisik sebagai upaya mitigasi struktural yang pembangunannya merupakan program dari REKOMPAK (Rehabilitasi dan Rekontruksi Masyarakat dan Permukiman Berbasis Komunitas) yang berkoordinasi dengan BPBD Kabupaten Magelang beserta pemerintahan dan masyarakat setempat.

Pembangunan jalur evakuasi utama dari Dusun Salamsari menuju TES (Tempat Evakuasi Sementara) yaitu Balai Desa Mranggen yang telah di aspal merupakan prioritas kegiatan pemulihan bencana sektor infrastruktur transportasi yang dilaksanakan oleh Badan Penanggulangan Bencana Daerah (BPBD) Kabupaten Magelang bidang 3 (bidang Rehabilitasi dan Rekontruksi pasca bencana Gunung Merapi). Jalan jalur evakuasi antar dusun yang telah dicor, dilaksanakan dengan adanya Program Nasional Pemberdayaan Masyarakat (PNPM) Mandiri Perdesaan bekerjasama dengan pemerintah dan masyarakat setempat.

\section{Mitigasi Non-Struktural}

Upaya mitigasi bencana non-struktural di Desa Mranggen sebagai Kawasan Rawan Bencana (KRB) III merupakan suatu upaya pengurangan risiko bencana melalui peningkatan penyadaran dan kemampuan masyarakat dalam menghadapi ancaman bencana. Kegiatan mitigasi non-struktural Desa Mranggen antara lain penyusunan modifikasi SOP PB (Standar Operasional Prosedur Penanggulangan Bencana) Gunung Merapi, penyusunan modifikasi 
Prosedur Tetap Penanggulangan Bencana (Protap PB), Prosedur Evakuasi, Sister Village, Peta KRB, OPRB (Organisasi Pengurangan Risiko Bencana), Penghutanan, Sosialisasi PB dan Alat Komunikasi HT (Handy Talky).

Standar Operasional Prosedur Penanggulangan Bencana atau disingkat SOPPB disusun sebagai pedoman proses penyelenggaraan penanggulangan bencana. Prosedur Tetap Penanggulangan Bencana Desa bertujuan untuk memberikan gambaran tentang tugas pokok dan fungsi serta tata kerja pengurangan risiko bencana di desa kepada segenap aparatur pemerintahan desa, organisasi/lembaga kemasyarakatan serta anggota masyarakat.

Prosedur evakuasi Desa Mranggen merupakan prosedur yang berisi kegiatan yang dilakukan untuk mengevakuasi warga saat terjadi ancaman bencana dari mulai titik kumpul, jalur dan sarana transportasi. Sister Village yaitu persaudaraan atau Desa bersaudara merupakan suatu kebijakan baru dalam penanggulangan bencana Gunung Merapi di Kabupaten Magelang, yaitu dengan melakukan kesepakatan dan kerjasama antara desa yang berada di KRB dengan desa yang dinilai lebih aman dari letusan Gunung Merapi. Desa bersaudara Desa Mranggen dalam upaya penanggulangan bencana Gunung Merapi adalah Desa Gunungpring dan Desa Sukorini, Kecamatan Muntilan.

Desa Mranggen dalam upaya mitigasi bencana non-struktural juga memanfaatkan peta sebagai media informasi dan sosialisasi kebencanaan, yang dipasang di aula pertemuan desa. Organisasi Pengurangan Risiko Bencana (OPRB) merupakan organisasi yang membantu pemerintah desa dalam pengurangan risiko bencana yang mencakup kegiatan mitigasi, kesiapsiagaan, tanggap darurat, pemulihan dan pembangunan berkelanjutan. Kegiatan penghutanan di Desa Mranggen merupakan kegiatan penanaman pohon-pohon keras, terutama di bantaran Sungai Putih. Kegiatan sosialisasi penanggulangan bencana Desa Mranggen dilakukan melalui pelatihan atau simulasi bencana yang sebagian besar dilaksanakan oleh Kesbangpollinmas, BPBD Kabupaten Magelang dan LSM. Alat komunikasi berupa HT (Handy Talky), bertujuan agar masyarakat yang aktif sebagai tim siaga bencana dapat memperoleh informasi kebencanaan secara cepat dan tepat.

\section{Tingkat Partisipasi Masyarakat pada Masing-masing Tahapan dalam Upaya Mitigasi Bencana di KRB III Desa Mranggen.}

Partisipasi masyarakat dalam kegiatan kebencanaan merupakan peran serta secara aktif masyarakat dalam kegiatan pengurangan risiko bencana. Partisipasi masyarakat dalam upaya pengurangan risiko bencana di Desa Mranggen diukur berdasarkan besarnya keterlibatan masyarakat dalam kegiatan mitigasi bencana baik struktural maupun nonstruktural mulai dari tahap identifikasi masalah, perencanaan, pelaksanaan, pemanfaatan dan pemeliharaan serta evaluasi berbagai kegiatan mitigasi yang dilaksanakan.

\section{Partisipasi Masyarakat dalam Tahap Identifikasi Masalah}

Partisipasi masyarakat dalam tahap identifikasi masalah merupakan kegiatan awal masyarakat dalam merencanakan upaya mitigasi bencana yang akan dilaksanakan. 
Berdasarkan penelitian yang telah dilakukan, dapat diketahui bahwa dari 100 reponden, yang mengetahui tentang rencana kegiatan mitigasi bencana di Desa Mranggen sebesar $66 \%$. Sebesar 56\% mendapat informasi dari pemerintah setempat dan sebesar 35\% mendapat informasi dari tokoh masyarakat, sedangkan responden yang aktif mencari informasi sendiri melalui berbagai media contohnya radio, televisi, majalah/koran dan lain sebagainya hanya sebesar $9 \%$.

Masyarakat yang terlibat dalam kegiatan identifikasi masalah kebencanaan sebesar 58\%. Masyarakat yang aktif dalam memberikan usulan atau pendapat sebesar 55\%. Motivasi responden yang terlibat dalam kegiatan identifikasi masalah antara lain karena kesadaran sebesar $76 \%$, ikut-ikutan sebesar $14 \%$, dan takut sebesar $10 \%$. Data tersebut menunjukkan bahwa sebagian besar masyarakat Desa Mranggen menyadari bahwa mereka berada di Kawasan Rawan Bencana yang mempunyai banyak masalah kebencanaan yang harus dihadapi.

Tingkat partisipasi masyarakat dalam tahap identifikasi masalah di Desa Mranggen, yang berada pada tingkatan rendah sebesar $49 \%$, tingkatan sedang sebesar $27 \%$ dan yang berada pada tingkatan tinggi sebesar $24 \%$. Sebesar $49 \%$ masyarakat pada tahap identifikasi masalah berada pada tingkatan rendah, artinya masyarakat Desa Mranggen belum sepenuhnya terlibat secara aktif dalam mengidentifikasi masalah kebencanaan yang ada di daerahnya.

\section{Partisipasi Masyarakat dalam Tahap Perencanaan}

Partisipasi masyarakat dalam tahap perencanaan kegiatan mitigasi bencana menunjukkan bahwa masyarakat terlibat aktif dan peduli bahwa permasalahan bencana merupakan tanggungjawab bersama. Masyarakat Desa Mranggen yang terlibat dalam perencanaan kegiatan mitigasi bencana baik struktural maupun nonstruktural sebesar $63 \%$. Masyarakat yang terlibat dalam kegiatan perencanaan sebesar $60 \%$ aktif memberikan usulan dan masukan dalam perencanaan kegiatan mitigasi bencana, diantaranya sebesar $81 \%$ mengusulkan jalur evakuasi agar diaspal atau diperbaiki. Masyarakat yang terlibat pada tahap perencanaan, sebagian besar terlibat dalam perencanaan pembangunan talud sebesar $92 \%$ dan jalur evakuasi sebesar 100\%, sedangkan untuk perencanaan kegiatan mitigasi non-struktural masyarakat terlibat dalam perencanaan perumusan Prosedur Tetap PB sebesar 31,7\%, Prosedur Evakuasi sebesar 33,3\%, Sosialisasi PB sebesar 41,3\% dan pembentukan OPRB sebesar 35\%.

Motivasi masyarakat yang terlibat dalam kegiatan perencanan kegiatan mitigasi bencana antara lain karena kesadaran sebesar $80 \%$, ikut-ikutan sebesar $14 \%$ dan takut sebesar $6 \%$. Sebagian besar masyarakat motivasinya adalah kesadaran karena masyarakat sadar bahwa kegiatan mitigasi bencana baik struktural maupun non-struktural harus direncanakan sebaik mungkin agar memberikan manfaat yang optimal, serta efektif dan efisien sesuai dengan tujuan yang diharapkan.

Tingkat partisipasi masyarakat dalam tahap perencanaan kegiatan mitigasi bencana di Desa Mranggen, yang berada pada tingkatan rendah sebesar $66 \%$, tingkatan sedang sebesar $32 \%$ dan yang berada pada tingkatan tinggi sebesar $2 \%$. Berdasarkan data tersebut, dapat diketahui bahwa sebesar $66 \%$ tingkat partisipasi masyarakat pada tahap 
perencanaan tergolong dalam klasifikasi rendah, hal tersebut disebabkan karena masyarakat yang terlibat dalam kegiatan perencanaan mitigasi bencana baik struktural maupun non-struktural biasanya orang-orang tertentu contohnya perangkat desa beserta seluruh kepala dusun dan tokoh masyarakat, yang dipandang memiliki kemampuan dan pengetahuan lebih luas sehingga diharapkan dapat mewakili aspirasi dan kepentingan seluruh masyarakat Desa Mranggen.

\section{Partisipasi Masyarakat dalam Tahap Pelaksanaan}

Kegiatan pelaksanaan mitigasi bencana baik struktural maupun non struktural di Desa Mranggen membutuhkan dukungan dari semua lapisan masyarakat. Masyarakat Desa Mranggen yang terlibat dalam kegiatan pelaksanaan mitigasi bencana sebesar 95\%, diantaranya terlibat dalam pembangunan talud sebesar $85 \%$ dan jalur evakuasi sebesar 91\% untuk mitigasi struktural, sedangkan untuk mitigasi nonstruktural masyarakat terlibat dalam pelaksanaan perumusan prosedur tetap PB, prosedur evakuasi, sosialisasi PB dan OPRB, masing-masing memiliki persentase kurang dari 50\% karena biasanya yang merumuskan dan mengikuti kegiatan adalah pihak tertentu yaitu kepala desa beserta perangkatnya termasuk seluruh kepala dusun dan tokoh masyarakat.

Sumbangan yang diberikan oleh masyarakat dalam pelaksanaan kegiatan mitigasi bencana berupa tenaga sebesar $100 \%$, sumbangan dana sebesar $38 \%$ dan sumbangan ide/gagasan sebesar 34\%. Motivasi masyarakat Desa Mranggen yang terlibat dalam kegiatan pelaksanaan kegiatan mitigasi bencana antara lain karena kesadaran sebesar $84 \%$, ikut-ikutan sebesar $13 \%$ dan takut sebesar 3\%. Motivasi masyarakat sebagian besar karena kesadaran (84\%), hal tersebut menunjukkan bahwa masyarakat Desa Mranggen dalam pelaksanaan kegiatan mitigasi bencana masih menjunjung tinggi nilai gotong royong antar sesama warga.

Tingkat partisipasi masyarakat dalam tahap pelaksanaan kegiatan mitigasi bencana di Desa Mranggen berada pada tingkatan rendah sebesar 5\%, tingkatan sedang sebesar $64 \%$ dan yang berada pada tingkatan tinggi sebesar $31 \%$. Berdasarkan data tersebut, dapat diketahui bahwa tingkat partisipasi masyarakat pada tahap pelaksanaan, sebagian besar berada pada tingkatan sedang (64\%), hal tersebut disebabkan karena masyarakat Desa Mranggen masih menjaga nilai gotong royong dan kerjasama sehingga mereka tidak merasa terpaksa terlibat dalam kegiatan pelaksanaan mitigasi bencana baik struktural maupun non-struktural.

\section{Partisipasi Masyarakat dalam Tahap Pemanfaatan dan Pemeliharaan}

Masyarakat wajib ikut serta dalam pemeliharaan berbagai upaya mitigasi bencana baik struktural maupun non-struktural yang dilaksanakan di daerahnya. Berdasarkan penelitian yang telah dilaksanakan, seluruh masyarakat terlibat dalam pemanfaatan berbagai kegiatan mitigasi bencana. Upaya mitigasi struktural yang sebagian besar dimanfaatkan masyarakat adalah talud sebesar $83 \%$ dan jalur evakuasi sebesar $96 \%$. Upaya mitigasi non-struktural yang banyak dimanfaatkan oleh masyarakat adalah sosialisasi penanggulangan bencana sebesar $60 \%$. Kegiatan sosialisasi bermanfaat bagi masyarakat sebagai upaya peningkatan penyadaran dan kemampuan masyarakat dalam menghadapi ancaman bencana. 
Masyarakat yang terlibat dalam pemeliharaan berbagai kegiatan mitigasi bencana Desa Mranggen sebesar 88\%. Partisipasi masyarakat dalam pemeliharan sebagian besar adalah melarang truk pengangkut pasir melewati jalur evakuasi, agar aspal tidak cepat rusak sebesar 78\%. Motivasi masyarakat Desa Mranggen yang terlibat pada tahap pemanfaatan dan pemeliharaan antara lain karena kesadaran sebesar $83 \%$, ikut-ikutan sebesar $13 \%$ dan takut sebesar $4 \%$.

Sebesar 92\% masyarakat Desa Mranggen memiliki tingkat partisipasi yang tinggi pada tahap pemanfaatan dan pemeliharaan berbagai upaya mitigasi bencana baik struktural maupun non-struktural. Masyarakat dengan tingkat partisipasi sedang sebesar $8 \%$, sehingga tidak ada masyarakat yang tingkat partisipasinya rendah. Sebagian besar masyarakat tingkat partisipasinya tinggi karena mereka sadar bahwa berbagai upaya mitigasi bencana harus dijaga dan dipelihara agar memberikan manfaat yang lebih lama.

\section{Partisipasi Masyarakat dalam Tahap Evaluasi}

Partisipasi masyarakat dalam tahap evaluasi merupakan tahap dimana masyarakat terlibat dalam kegiatan mitigasi bencana untuk memberikan penilaian terhadap berbagai kegiatan yang telah dilaksanakan, apakah sudah sesuai dengan kebutuhan atau masih ada yang harus diperbaiki. Masyarakat yang terlibat dalam kegiatan evaluasi mitigasi bencana sebesar $65 \%$. Masyarakat yang terlibat dalam kegiatan evaluasi, sebesar $48 \%$ terlibat aktif dalam memberikan usulan/masukan diantaranya sebesar $87 \%$ mengusulkan jalan dusun menuju jalur evakuasi harus di aspal atau diperbaiki (dicor), sebesar $64 \%$ mengusulkan agar kegiatan sosialisasi penanggulangan bencana harus dilakukan secara kontinyu dan tepat sasaran.

Motivasi masyarakat Desa Mranggen terlibat dalam kegiatan evaluasi mitigasi bencana antara lain karena kesadaran sebesar $81 \%$, ikut-ikutan sebesar $11 \%$ dan takut sebesar $8 \%$. Data tersebut menunjukkan bahwa sebagian besar motivasi masyarakat yang terlibat dalam kegiatan evaluasi adalah kesadaran (81\%), artinya mereka memiliki kepedulian tinggi terhadap hasil kegiatan yang dilaksanakan di desanya.

Sebesar 53\% masyarakat Desa Mranggen memiliki tingkat partisipasi yang tinggi pada tahap evaluasi sehingga menunjukkan bahwa masyarakat memiliki kepedulian dan kesadaran untuk menindak lanjuti berbagai kegiatan yang dilaksanakan. Masyarakat dengan tingkat partisipasi sedang sebesar $11 \%$, dan masyarakat yang tingkat partisipasinya rendah sebesar $36 \%$. Keterlibatan masyarakat pada tahap evaluasi, tujuannya adalah meningkatkan kemampuan masyarakat untuk menilai kesesuaian maupun kekurangan terhadap hasil kegiatan mitigasi bencana, apakah sesuai kebutuhan ataukah belum. Apabila belum maka kegiatan evaluasi ini, dapat digunakan sebagai pedoman perencanaan kegiatan mitigasi bencana di masa depan agar lebih sesuai dengan kebutuhan masyarakat.

Tingkat Partisipasi Masyarakat dalam Mitigasi Bencana di KRB III Desa Mranggen

Tabel 1. Tingkat Partisipasi Masyarakat dalam Upaya Mitigasi Bencana di Desa Mranggen

\begin{tabular}{|c|l|c|c|}
\hline No. & Tingkat Partisipasi Masyarakat & Frekuensi & Presentase \\
\hline 1 & Rendah & 32 & 32 \\
\hline 2 & Sedang & 36 & 36 \\
\hline
\end{tabular}




\begin{tabular}{|c|c|c|c|}
\hline 3 & Tinggi & 32 & 32 \\
\hline \multicolumn{2}{|c|}{ Jumlah } & 100 & 100 \\
\hline
\end{tabular}

Sumber : Data Primer, 2014

Tingkat partisipasi masyarakat Desa Mranggen dalam upaya mitigasi bencana baik struktural maupun non struktural, yang tergolong dalam tingkat partisipasi tinggi sebesar $32 \%$, tingkat partisipasi sedang sebesar 36\%, dan tingkat partisipasi rendah sebesar $32 \%$. Melihat data keseluruhan maka dapat disimpulkan bahwa tingkat partisipasi masyarakat dalam upaya mitigasi bencana di Desa Mranggen tergolong dalam tingkatan sedang yaitu sebesar $36 \%$. Hal tersebut dapat dijelaskan mengggunakan tabel tingkat partisipasi masyarakat dalam upaya mitigasi bencana pada masing-masing tahapan partisipasi sebagai berikut:

Tabel 2. Tingkat Partisipasi Masyarakat pada Masing-masing Tahapan dalam Upaya Mitigasi Bencana di Desa Mranggen

\begin{tabular}{|c|c|c|c|c|c|c|c|c|c|c|c|}
\hline \multirow[t]{3}{*}{ No. } & \multicolumn{11}{|c|}{ Tahapan Penelitian } \\
\hline & \multirow[t]{2}{*}{$\begin{array}{l}\text { Kategori } \\
\text { Parameter }\end{array}$} & \multicolumn{2}{|c|}{$\begin{array}{l}\text { Identifikasi } \\
\text { Masalah }\end{array}$} & \multicolumn{2}{|c|}{ Perencanaan } & \multicolumn{2}{|c|}{ Pelaksanaan } & \multicolumn{2}{|c|}{$\begin{array}{l}\text { Pemanfaatan } \\
\text { dan } \\
\text { Pemeliharaan }\end{array}$} & \multicolumn{2}{|c|}{ Evaluasi } \\
\hline & & Jiwa & $\%$ & Jiwa & $\%$ & Jiwa & $\%$ & Jiwa & $\%$ & Jiwa & $\%$ \\
\hline 1 & Rendah & 49 & 49 & 66 & 66 & 5 & 5 & 0 & 0 & 36 & 36 \\
\hline 2 & Sedang & 27 & 27 & 32 & 32 & 64 & 64 & 8 & 8 & 11 & 11 \\
\hline 3 & Tinggi & 24 & 24 & 2 & 2 & 31 & 31 & 92 & 92 & 53 & 53 \\
\hline \multicolumn{2}{|c|}{ Jumlah } & 100 & 100 & 100 & 100 & 100 & 100 & 100 & 100 & 100 & 100 \\
\hline
\end{tabular}

Sumber : Data Primer, 2014

Tingkat partisipasi masyarakat Desa Mranggen dikategorikan dalam tingkatan sedang karena dalam tahapan kegiatan partisipasi masyarakat, keikutsertaan masyarakat bervariasi. Pada tahap identifikasi masalah, tingkat partisipasi masyarakat tergolong rendah (49\%), karena masyarakat kurang mempunyai kepedulian terhadap masalah kebencanaan yang harus dihadapi di daerahnya. Begitu pula pada tahap perencanaan, tingkat partisipasi masyarakat Desa Mranggen juga tergolong rendah (66\%) karena biasanya yang terlibat dalam perencanaan berbagai kegiatan mitigasi bencana, hanya orang tertentu seperti kepala desa beserta perangkatnya termasuk seluruh kepala dusun dan tokoh masyarakat.

Pada tahap pelaksanaan, tingkat partisipasi masyarakat tergolong sedang (64\%), hal ini menunjukkan bahwa nilai gotong royong dan kerjasama masih dijunjung tinggi oleh masyarakat Desa Mranggen. Pada tahap pemanfaatan dan pemeliharaan, hampir seluruh masyarakat yang menjadi responden berada pada tingkatan partisipasi tinggi (92\%), karena masyarakat menyadari bahwa berbagai kegiatan mitigasi bencana akan memberikan manfaat besar bagi masyarakat dalam upaya penanggulangan bencana. Tingkat partisipasi masyarakat pada tahap evaluasi, tergolong berada pada tingkatan tinggi (53\%), berarti mereka mempunyai kepedulian dan kepekaan yang tinggi dalam mengevaluasi berbagai kegiatan mitigasi bencana yang telah dilaksanakan .Berdasarkan penjelasan tersebut, dapat disimpulkan bahwa tingkat partisipasi masyarakat dalam upaya mitigasi bencana Desa 
Mranggen tergolong dalam tingkatan sedang, dengan rata-rata skor nilai keseluruhan responden pada masing-masing tahapan partisipasi yang menunjukkan angka 22,64.

\section{SIMPULAN}

Berdasarkan pemaparan diatas dapat diambil beberapa kesimpulan antara lain: (1) Upaya mitigasi struktural di Desa Mranggen diantaranya melalui pembangunan fisik berupa Check dam, Sabo dam, Operit, Jembatan Gantung, Tanggul/Bronjong, Talud/Drainase, dan Jalur Evakuasi. Upaya mitigasi non-struktural di Desa Mranggen dilakukan dengan menyusun modifikasi SOP PB, Prosedur Tetap Penanggulangan Bencana (Protap PB), Prosedur Evakuasi, Program Sister Village, Peta KRB, OPRB (Organisasi Pengurangan Risiko Bencana), Penghutanan, Sosialisasi PB dan Alat Komunikasi HT (Handy Talky). (2) Tingkat partisipasi masyarakat dalam upaya mitigasi bencana di KRB III Gunung Merapi Desa Mranggen, tergolong dalam tingkatan "sedang" yaitu dengan rata-rata skor nilai keseluruhan responden pada masing-masing tahapan partisipasi yang menunjukkan angka 22,64. Hal tersebut menunjukkan bahwa keterlibatan responden dalam berbagai tahapan kegiatan mitigasi bencana bervariasi, sehingga masyarakat kurang aktif terutama dalam memberikan sumbangan pemikiran bagi berbagai kegiatan mitigasi bencana baik struktural maupun non-struktural di Desa Mranggen.

\section{UCAPAN TERIMA KASIH}

Tulisan ini merupakan bagian dari tugas akhir skripsi dengan judul partisipasi masyarakat dalam upaya mitigasi bencana di kawasan rawan bencana (KRB) III Desa Mranggen, Kecamatan Srumbung, Kabupaten Magelang. Penulis menyampaikan terima kasih kepada pembimbing tugas akhir dan berbagai pihak yang telah membantu dalam pelaksanaan penelitian, khususnya masyarakat Desa Mranggen sebagai responden dalam penelitian ini.

\section{DAFTAR PUSTAKA}

Suharsimi, Arikunto. (2006).Prosedur Penelitian Suatu Pendekatan Praktik. Jakarta : PT Rineka Cipta

Sutrisno Hadi. (2000). Statistik Jilid 1. Yogyakarta: Andi 